\title{
A SUSTAINABLE HOMESTEAD PROTOTYPE IN SUNDARBANS Disaster adaptability through alternative building materials
}

\author{
BHUIYAN R.H.1, 3 SHIRIN S. ${ }^{2,3}$, \& PAUL SHOUROV K. ${ }^{2}$ \\ ${ }^{1}$ Bangladesh University of Engineering and Technology, Dhaka, Bangladesh \\ ${ }^{2}$ Chittagong University of Engineering and Technology, Chittagong, Bangladesh \\ ${ }^{3}$ These authors contributed equally to this paper \\ raquibulhassan.tonmoy@gmail.com , u1306008@student.cuet.ac.bd
}

\begin{abstract}
Sundarbans as the primary coastal defense of Bangladesh against various natural disaster encounters recurrent homelessness due to these calamities, resulting in cutting down forests for housing materials from the only nearby resource. The traditional vernacular practice and socio-cultural studies show a symbiotic relationship between the forest and inhabitants, but the ecological imbalance created by climate change made life difficult for them, whose livelihood solely depends on the forest as well. The inability to reuse the building materials any disaster causes an everincreasing cycle of carbon footprint. Regarding these, the non-experimental research aims to build such a homestead prototype that creates an adaptable solution. The existing building practices consist of non-reusable materials, poor structural integrity, and lack of sustainable approaches, thus unfit to withstand the increasing disasters and calamities. The approach discussed here utilizes plastic waste, drums, bamboo for disaster adaptability, structural flexibility, rainwater harvesting, solar, and biogas energy for a sustainable lifestyle. So, the goal is to provide a sustainable solution for the economically challenged population. This prototype creates an adaptive strategy for mitigating the disastrous events in Sundarbans to promote resilience and sustainability.
\end{abstract}

Keywords: Recycled material; Disaster adaptability; Sundarbans; Sustainability

\section{Introduction}

When it comes to housing types there are variations based on time, place and surrounding of the house or an entire community of housing. Tradition and culture based influences as well as available resources are also impactful for a specific housing style. In our South Asian region housing design also varies in international scale as well as in regional scale where an individual or unique situation rises.

The Sundarbans is such a unique region with its biodiversity and special ecosystem. The diverse plant and wildlife assemblages, and economically significant fisheries are also part of this unique ecosystem that spread beyond an international border, political and socio-economic differences. Nearly 0.1 percent of the global population, amongst the poorest in the region, is directly dependent on the Sundarbans for their livelihood (Nishat, 2019). The green wonder and largest mangrove forest in the world are in the south of Bangladesh and India distributed unequally between these two nations through a shared international border. (Jalais, 2010)

Due to its geographic location the largest piece of uninterrupted mangrove habitation of the world is a highlight for many natural disasters. The common natural hazards that the Sundarbans region faces regularly are-frequently occurring cyclones, irregular flood, the ever-rising sea level that is causing the decreasing land area of the forest. Severe cyclones and storm surge causes most of the inhabitants to rebuild their homestead, resulting in an ever-increasing cycle of carbon footprint. The northern area of the forest spreads urban settlement at a fast rate, creating huge amounts of plastic wastes contaminating the forest area. The plastics increased wildly in the marine environment, due to the huge number of plastics carried into this arena by tourists (Ghosh, 2020). 
Pointing out all these factors, an affordable homestead prototype can be proposed to tackle this crisis to some extent. The prototype utilizes recycled materials like plastic brick and steel drums for flood adaptability, bamboo for structural stability, rainwater harvesting, solar, and biogas energy for a sustainable lifestyle. The purpose of this research is to build a durable homestead following the existing building materials and technique of the respected region.

\section{Aim and Objectives}

There is both natural and manmade reason for damage of the Sundarbans. Natural disasters like floods and cyclones have been occurring at regular intervals and causing numerous damages to its social and cultural environment. The aim of the research is to propose an alternative solution to build a homestead with structural adaptability.

The objective is to design a homestead prototype that is-

- AFFORDABLE because of the cost-effective building materials and maintenance.

- REUSES MATERIALS that are resourceful as well considering the surrounding regions.

- $\quad$ RESILIENT to natural catastrophes like, cyclones and floods.

- $\quad$ SUSTAINABLE by affecting the ecosystem very minimally.

- $\quad$ CREATIVE design expression and resolution while reflecting the culture of the place.

- IMPLEMENTABLE for fast scaling up of the execution by the authorities, NGOs, and individuals.

\section{Methodology}

The present homestead practices consist of such materials that shows poor structural integrity and lacks resilience. So, they are unfit to withstand the catastrophe due to its geographical location. Through various literature studies and field survey, the social, economic, and environmental aspects were gathered, combined with the architectural practice that was present in their typical community structure. From these findings the special factors that a homestead in a unique context such as the Sundarbans region needed was sorted out. Then the search for alternate materials that can withstand or can be rearranged after a disaster was explored. All these materials were assembled into a courtyard-based design style respecting the already practicing homestead in the region. Overall, a climate resilient and context friendly approach was taken to provide for the disaster affected people through a cost-effective design.

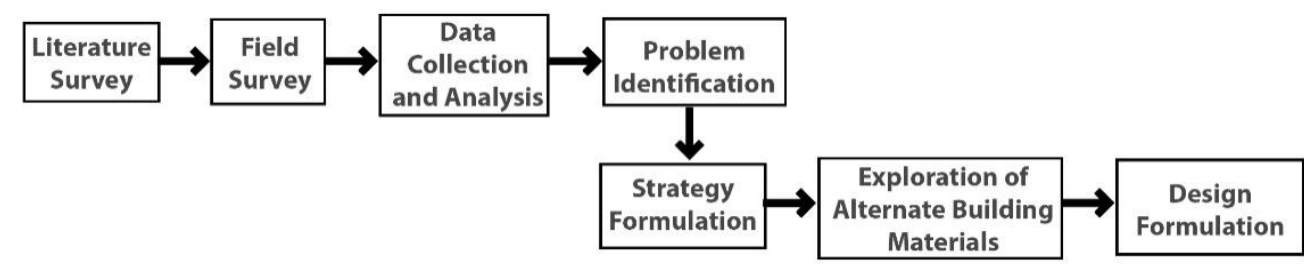

Figure 1, Methodology Process

(Source-Author)

\section{Contextual Analysis}

The study area analysis shows the surrounding context on different scalar levels. On a closer scale, the socio-economic and environmental aspects are analyzed to understand the use of space and sustainable vernacular practices.

\subsection{STUDY AREA}

In recent times, Bangladesh, especially coastal sides, and Sundarbans mangrove forests, face tropical cyclones frequently. In this case, the coastal areas and Sundarbans areas are more affected. The people there become homeless, and their livelihood comes to a standstill. For this reason, Munshiganj union under Shyamnagar Upazila located in the Satkhira district has been selected as a case study area (Figure 2). Munshiganj union was mainly separated by the Maloncho River from Sundarbans which is in the south side. Its total area is only 39 square Kilometer. The distance between the Munshiganj union and the Upazila headquarter is about $15 \mathrm{Km}$ and $70 \mathrm{~km}$ from Satkhira district headquarter. The North and East side of the union is surrounded by Burigoalini union, and the west side is surrounded by Isshawripur union (Profile of Munshiganj Union, 2014). 


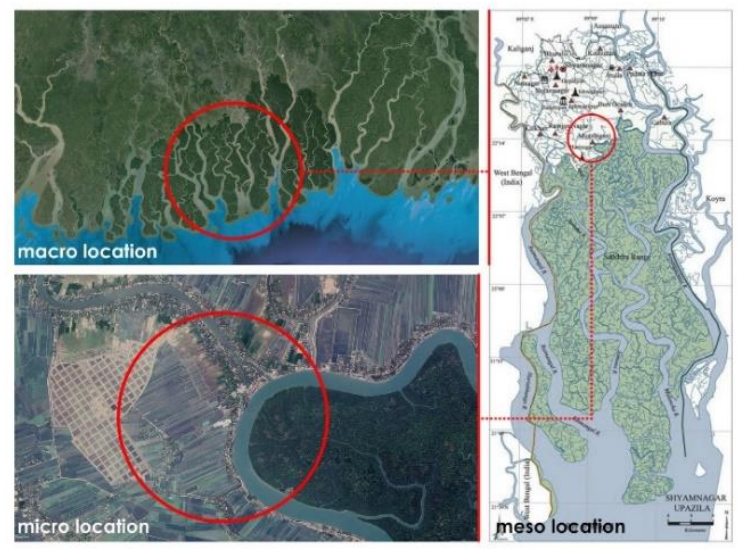

Figure 2, Site Location in Different Scales (Source: Google Earth; Shyamnagar UpazilaBanglapedia, 2014)

\subsection{SOCIO-ECONOMIC ASPECT:}

Sunderbans resources and the location of households in the forest formulated the socio-economic structure that now prevails in the jungle. The social aspect adjacent to the forest rises with its society and community. The area is of great scenic beauty, biodiversity and rivers, as well as festivals, local cultural art forms and places of religious interest. There are locations of scenic views for tourists as well (Nishat, 2009). Their homesteads are also arranged in such a way so that a community may grow with a good relation and dependency among each other. This is how the space relation is also created among their households.

The three main socio-economic groups of the Sundarbans region can be categorized into two major categories according to their location of homestead or location of their livelihood,_named as 'people from the river's edge' (nodir kuler lok) and 'people from the locality of the school' or the 'bhadralok' (Jalais, 2010). The bhadralok class people are the main and primary group of landowners. These people mostly live on the northern sides of the forest. Another economic group consists of comparatively less established ones than the first group. This class is economically dependent on the forest and forest resources. Among this class exist the forest workers and the fishermen.

\subsection{ENVIRONMENTAL ASPECT}

The surrounding environment of the site area is greatly influenced by the mangrove forest, Sundarbans. The human settlers of the forest go by their social structures and most of their regular livelihood depends on the welfare of the forest. So, this area is so susceptible to the cyclones, heavy rainfall and tidal waves which are most frequently seen to happen near Sundarbans and coastal sides of Bangladesh. For example, Cyclone Sidr in 2007, Cyclone Aila in 2009, Cyclone Fani in 2019 and Cyclone Amphan in 2020 hit this area and its surroundings.

An overview of the total damage caused by Sidr in 2007 shows that according to DMCR, 141 upazilas and 1,119 unions were affected. Almost 3,00,511 houses were completely destroyed and 6,26,000 houses were partially destroyed. (Ali Manik and Khan, 2007). In recent times, cyclone Amphan caused 374 houses to collapse completely and partial damage to 4,349 houses in nine upazilas in the nearby Bagerhat District. In Satkhira, a district of the study area, almost 83,560 houses were damaged (Bangladesh: Coastal districts hit hard by Amphan, 2020).

Natural disasters such as Cyclonic storms and tidal surges greatly affect the biodegradable communities of the forest edge with sea side by uprooting plants, eroding coastal soils, breaking stems and branches, human settlements and lives (Aziz and Paul, 2015). Besides, due to sea level rise, a definite inward intrusion of the salinity front causes the different species of plants and animals to be adversely affected. So, the impact on the environment is pretty diverse based on different sources. And to maintain the environment, the people need a homestead that is both climate resilient and economically affordable.

\subsection{BUILDING MATERIALS STUDY THROUGH TYPOLOGIES}

The building materials were studied using the housing module as clusters and analyzing how different materials served to the need of the typology and what the benefits and limitations of the materials are in the context. 


\subsubsection{Typology 1}

This typology is the widely used vernacular practice in the area. As mud is found predominantly in the area and because of the cheap cost, the low-income people use this material as their primary building material. The mud wall generally has bamboo structure to support the thatched roof using "Golpata" (Nypa fruticans), another common material found in the region (Figure 3). For various activities they use the front courtyard as an extension of the house. The plinth is elevated to withstand the regular tidal water rise, although the measure doesn't cope with cases of flood due to disaster events. The primary problem of this material is its lack of durability in monsoon and flood events. As the mud washes away in the water flow, the house needs to be maintained and rebuilt time and time again.
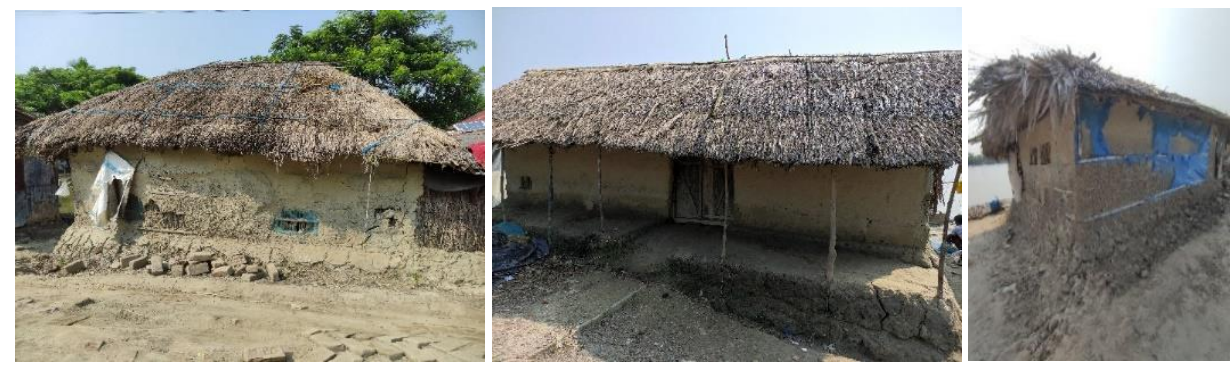

Figure 3, Elevation of mud house (left), semi-private "dawakhana” (verandah) outside main house (middle), high plinth to withstand flood (right)

(Source-Author)

\subsubsection{Typology 2}

This typology varies greatly due to the different combinations of different materials altogether. As the inhabitants have better income opportunities, they can use wood panels as walls, and can use cement overlay on top of the mud plinth so that the water cannot wash away the mud frequently (Figure 4). For roofing material, corrugated sheet is used widely. Their use of wood panel wall instead of mud and cement overlay on plinth instead of only mud is dependent on their affordability.
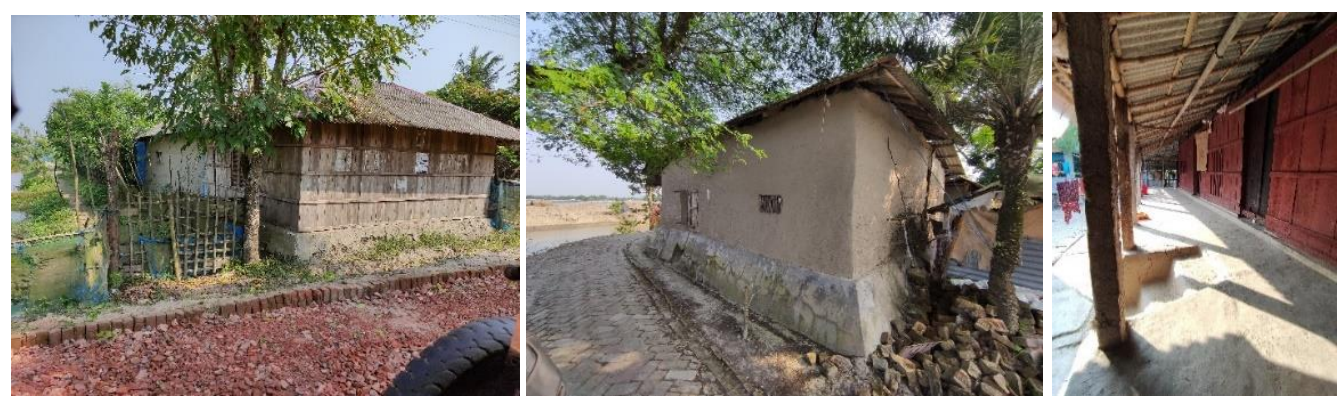

Figure 4, Mud plinth covered with cement and wooden walls (left), mud plinth covered with cement and mud walls (middle), mud plinth and wooden walls (right)

(Source-Author)

\subsubsection{Typology 3}

For the affluent families, this typology is seen using complete brick structure with cement overlay (Figure 5). This type of buildings cost a lot but it provides a better building material to withstand the daily water level rise and the violent storms to some extent. But in case of severe flood, these buildings get inundated as well. The lack of affordability causes this typology practiced rarely in number in the area, as most of the inhabitants living in the area need an affordable solution. 


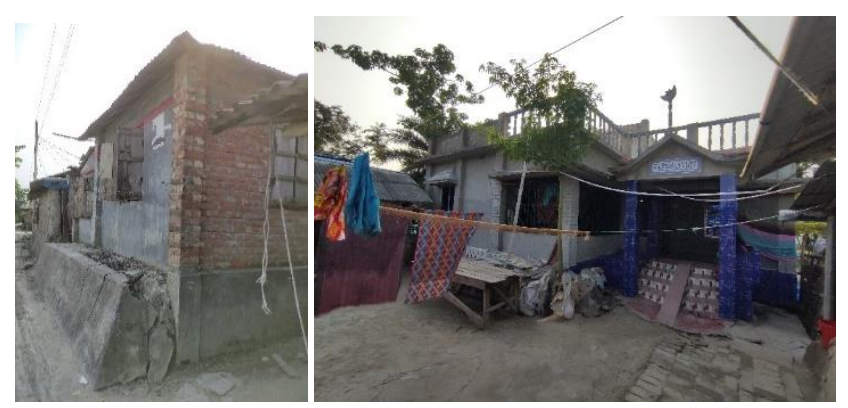

Figure 5, Brick building with columns

(Source-Author)

\subsection{VERNACULAR SPACE DISTRIBUTION}

Among different typologies, the space distribution are more or less common. The traditional approach is the formation of an inner semi-private courtyard entered indirectly from the road with the placement of rectangular masses around. This courtyard is one of the most important vernacular factor of the rural homesteads. Different domestic activities like cooking, drying clothes, storing firewoods happens here. It is also used for the playground for children and a space of communition between households (Figure 6).
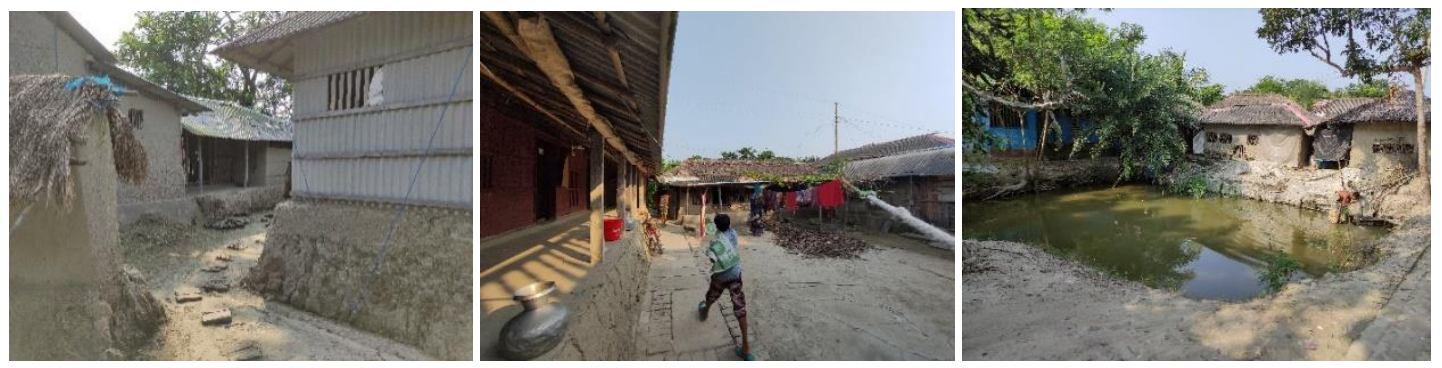

Figure 6, Indirect entry to the courtyard (left), multipurpose use of open courtyard (middle), use of pond (right)

(Source-Author)

The houses are mainly used for sleeping and storing goods, which can be accessed from the courtyard but not from the adjacent road. Generally, the shops face the road, which is used for different economic activities and can be an extension of the house. Ponds and vegetable garden are also very important elements of the homestead which are used and maintained by the families for water and food (Figure 7).
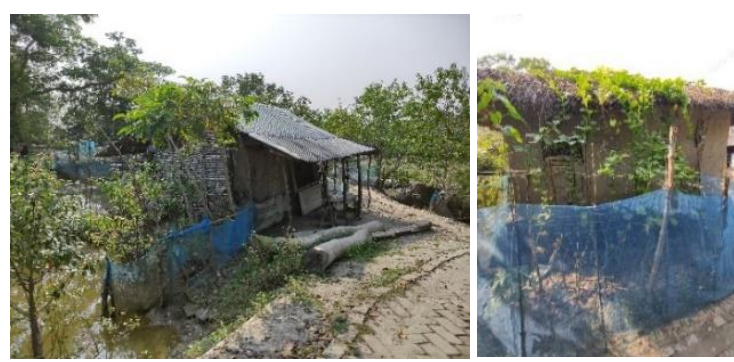

Figure 7, Location of shop by the roadside (left), growth of vegetable garden (right) (Source-Author)

\section{Lessons Learnt Form Contextual Analysis}

The vernacular space distribution provides important guidelines about the spatial requirements of both outdoor and indoor activities. The homestead thrives upon the multipurpose use of the courtyard, pond and vegetable garden act as important sources of water and food. Through the assessment of building material through typological study, we were able to identify multiple benefits and limitations of different materials in the contextual application (Table 1). 


\begin{tabular}{|c|c|c|c|c|}
\hline Typology name & & No. 1 & No. 2 & No.3 \\
\hline Shape and Dimension & & $\begin{array}{l}\text { Rectangular, generally } \\
10^{\prime} \times 15^{\prime}\end{array}$ & $\begin{array}{l}\text { Rectangular, generally } \\
200^{\prime} 15^{\prime}\end{array}$ & Varied shape and size \\
\hline \multirow{4}{*}{ Materials Used } & Plinth & $\begin{array}{l}\text { Mud, generally raised at } \\
2 \text { ' or more }\end{array}$ & $\begin{array}{l}\text { Mud, can be covered with } \\
\text { cement, generally raised } \\
\text { at 2' or more }\end{array}$ & $\begin{array}{l}\text { Brick, covered with } \\
\text { cement, generally raised } \\
\text { at } 2 \text { ' or more }\end{array}$ \\
\hline & Wall & $\begin{array}{l}\text { Mud, acts as a load } \\
\text { bearing wall }\end{array}$ & $\begin{array}{l}\text { Wooden planks/ } \\
\text { corrugated sheet }\end{array}$ & $\begin{array}{l}\text { Brick wall, can be } \\
\text { plasterd }\end{array}$ \\
\hline & Structure & & $\begin{array}{l}\text { Bamboo/ Wooden post/ } \\
\text { Prefabricated concrete } \\
\text { post }\end{array}$ & Brick/concrete columns \\
\hline & Roof & $\begin{array}{l}\text { Thatched roof using } \\
\text { "Golpata" }\end{array}$ & Corrugated Metal sheet & $\begin{array}{l}\text { Corrugated sheet/ } \\
\text { concrete slabs }\end{array}$ \\
\hline User Group & & Low-income group & Middle income group & High income group \\
\hline Positive aspects & & low-cost material & $\begin{array}{l}\text { 1. low-cost material } \\
\text { 2. cement cover on plinth } \\
\text { reduce mud corrosion }\end{array}$ & $\begin{array}{l}\text { 1. can withstand typical } \\
\text { water rise and storms } \\
\text { 2. doesn't need to be } \\
\text { maintained as mud }\end{array}$ \\
\hline Negative aspects & & $\begin{array}{l}\text { 1. maintained and } \\
\text { rebuilt continuously } \\
\text { 2. cannot withstand } \\
\text { violent storms } \\
\text { 3. inundates in flood } \\
\text { event }\end{array}$ & $\begin{array}{l}\text { 1. cannot withstand } \\
\text { violent storms } \\
2 . \text { inundates in flood } \\
\text { event }\end{array}$ & $\begin{array}{l}\text { 1. costly material and } \\
\text { construction } \\
2 . \text { inundates in flood } \\
\text { event } \\
\text { 3. if destroyed in } \\
\text { disasters bricks cannot } \\
\text { be reused }\end{array}$ \\
\hline
\end{tabular}

Table 1. Assement of Building Typology

\section{Case Study}

There are various incentives applied by various organizations to build resilient houses in coastal areas, low lying areas which are susceptible to disasters. Among them, two case studies are described below which are relevant to our proposed homestead type.

\subsection{CASE STUDY 1}

The first disaster-resilient habitat, developed by United Nations Development Program (UNDP) teamed up with architects from BRAC has been built up in Shyamnagar, Satkhira, Bangladesh which is adjacent to our study area (Figure 8). The main concept of this making habitat is to protect properties from tidal surges due to cyclones. There are 50 houses on $2 \mathrm{~m}$ concrete stilts in this habitat. Considering tidal surges and seasonal water level rise, the ground level is six feet high from the land fixed by concrete pillar. And, the roof truss of this houses are able to withstand up to $150 \mathrm{mph}$ wind velocity.
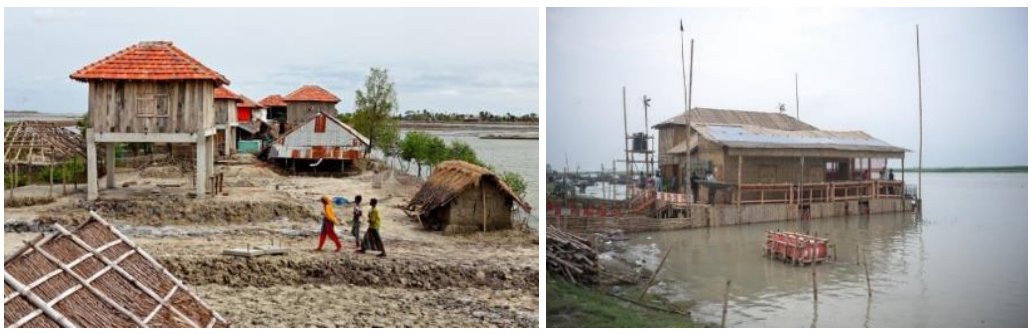

Figure 8, Case Study 1 (Left) (Purvis, 2015); Case Study 2 (Right) (Mukherjee, 2019)

\subsection{CASE STUDY 2}

A project, titled "A Dream House" has been developed for flood affected peoples in Dular Chor area of Shariatpur's Bhedarganj, Bangladesh. This project, funded by the Global Resilience Partnership (GRP), has been implemented with the help of a team of Brac's University's Center for Climate Change and Environmental Rsesearch (C3ER). This house contains three houses and each houses are covering three kathas. This house is mainly made of bamboo, wood and plastic barrels (Figure 8). Mainly, plastic barrels which weigh over 40 ton acts as a buoyant platform of allowing the house to withstand above floodwater 
by sliding two guideposts. Apart from, this structure is able to bear the category three cyclones, mediumlevel earthquakes and river erosion.

\section{Rethinking the Homestead Prototype}

The design process acted as a bridge between the good existing vernacular practices and the necessary improvisations to meet the design challenges. The process started by formulating mitigation strategies relevant to the problems, which were obtained from the literature and field study. Also, strategies employed in the case studies helped to formulate design component and strategies for the site area (Table 2).

\begin{tabular}{|c|c|c|}
\hline $\begin{array}{c}\text { Design } \\
\text { Components }\end{array}$ & Problems & Possible Mitigation Strategies \\
\hline $\begin{array}{c}\text { Water rise and } \\
\text { flood Resistance }\end{array}$ & $\begin{array}{c}\text { Due to tide, the water rises occasionally. The typologies have } \\
\text { raised plinth to keep the floor above water for this scenario, } \\
\text { but in case of flood and storm surges, the houses get } \\
\text { submerged. }\end{array}$ & $\begin{array}{c}\text { Floating structure can help to adapt with } \\
\text { both the water rise and flood events. }\end{array}$ \\
\hline Storm Resistance & $\begin{array}{c}\text { Only the brick buildings in typology 3 can withstand the } \\
\text { storms to some extent, but due to affordability problems, it } \\
\text { cannot be widely practiced. }\end{array}$ & $\begin{array}{c}\text { Proper structural adaptability with low- } \\
\text { cost materials can be utilized. }\end{array}$ \\
\hline Material Durability & $\begin{array}{c}\text { Mud, Golpata, wooden post etc. cannot be used due to its } \\
\text { deterioration due to water submergences and rain. }\end{array}$ & $\begin{array}{c}\text { Durable material or proper treatment to } \\
\text { natural materials to increase durability } \\
\text { can be used. }\end{array}$ \\
\hline
\end{tabular}

Table 2. Contextual Problem Identification and Possibility of Mitigation Strategies

\subsection{ALTERNATE MATERIAL STUDY}

Based on the design components, a study was conducted on the available alternate materials that suited the component best. The analysis based on the study showed various positive and negative aspects of the materials that helped to choose the best option for the implementation of the relevant mitigation strategy. (Table 3).

\begin{tabular}{|c|c|c|c|c|}
\hline Component & $\begin{array}{l}\text { Material } \\
\text { Options }\end{array}$ & Positive Aspects & Negative Aspects & Remarks \\
\hline \multirow[t]{2}{*}{$\begin{array}{l}\text { Floating } \\
\text { Structure }\end{array}$} & $\begin{array}{l}\text { Plastic } \\
\text { Drums }\end{array}$ & $\begin{array}{l}\text {-high density industrial strength polymer with } \\
\text { thick walls that provide endurance, strength, and } \\
\text { longevity (Search and Drums, n.d.) } \\
\text {-can take significant weight and that will be } \\
\text { approximately } 450 \text { pounds when the barrel is } \\
99 \% \text { submerged (How many } 55 \text { gallon drums for } \\
\text { this size dock?, 2010) } \\
\text {-the drums can be reused without diminishing its } \\
\text { value }\end{array}$ & $\begin{array}{l}\text {-without coating, it cannot } \\
\text { use for long term }\end{array}$ & \multirow[t]{2}{*}{$\begin{array}{l}\text { Plastic drum is } \\
\text { the better option } \\
\text { because of its } \\
\text { durability and } \\
\text { Recyclable } \\
\text { capacity }\end{array}$} \\
\hline & $\begin{array}{l}\text { Inflating } \\
\text { Rubber }\end{array}$ & -can be deflated when necessary & $\begin{array}{l}\text { - any leak in the surface can } \\
\text { cause permanent damage }\end{array}$ & \\
\hline \multirow{2}{*}{$\begin{array}{c}\text { Structural } \\
\text { Adaptabilit } \\
\text { y }\end{array}$} & Timber & $\begin{array}{l}\text {-locally found } \\
\text {-good load bearing capacity }\end{array}$ & $\begin{array}{l}\text { - can get deteriorated with } \\
\text { continuous exposure to } \\
\text { water } \\
\text {-over sourcing of timber } \\
\text { causing deforestation of the } \\
\text { nearby forest }\end{array}$ & \multirow{2}{*}{$\begin{array}{l}\text { Bamboo is the } \\
\text { better option } \\
\text { only if treatment } \\
\text { is applied }\end{array}$} \\
\hline & $\begin{array}{c}\text { Prefabricat } \\
\text { ed } \\
\text { concrete } \\
\text { column }\end{array}$ & $\begin{array}{l}\text {-can be mass produced } \\
\text {-easy to buy as a } 5{ }^{\prime \prime} 5^{\prime \prime} \times 10^{\prime} \text { modules }\end{array}$ & $\begin{array}{l}\text {-incremental growth is not } \\
\text { supported with this type of } \\
\text { structure } \\
\text { - can get deteriorated with } \\
\text { continuous exposure to } \\
\text { water }\end{array}$ & \\
\hline
\end{tabular}




\begin{tabular}{|c|c|c|c|c|}
\hline & Bamboo & $\begin{array}{l}\text {-From Japanese studies bamboo can capture } 12 \\
\text { tons of carbon dioxide per hectare per year, } \\
\text { whereas Chinese estimates are more like } 5 \text { tons } \\
\text { per hectare. (Hornaday, 2020) } \\
\text {-higher tensile strength than steel because its } \\
\text { fibers run axially. } \\
\text {-easily displaced or installed making it very } \\
\text { easier for transportation and construction due to } \\
\text { low weight } \\
\text {-Unlike other building materials like cement and } \\
\text { asbestos, bamboo poses no danger to health. } \\
\text { (Bamboo as a Building Material - its Uses and } \\
\text { Advantages in Construction, 2021) }\end{array}$ & $\begin{array}{l}\text {-without treatment, it has } \\
\text { short life span } \\
\text {-shrinking much greater } \\
\text { than any other type of } \\
\text { timber especially when it } \\
\text { loses water. }\end{array}$ & \\
\hline \multirow{3}{*}{$\begin{array}{l}\text { Durable } \\
\text { wall and } \\
\text { floor } \\
\text { material }\end{array}$} & $\begin{array}{l}\text { Plastic } \\
\text { Brick }\end{array}$ & $\begin{array}{l}\text {-5-7 times stronger than concrete (Dhaka } \\
\text { Tribune, 2021) } \\
\text {-saving 5,774 Kwh of energy, } 16.3 \text { barrels of oil, } \\
98 \text { million BTU's of energy, and } 30 \text { cubic yards of } \\
\text { landfill space from } 1 \text { ton of recycled plastic } \\
\text { wastage (Frequently Asked Questions: Benefits of } \\
\text { Recycling | Land, Buildings \& Real Estate, n.d.) } \\
\text { - Production cost of plastic brick is 30\% lower } \\
\text { than the conventional burnt brick. (Open-Source: } \\
\text { Recycled Brick, 2020) }\end{array}$ & $\begin{array}{l}\text { - needs machinery support } \\
\text { for production }\end{array}$ & \multirow{3}{*}{$\begin{array}{l}\text { Plastic brick is } \\
\text { the better option } \\
\text { because of its } \\
\text { durability and } \\
\text { upcycling } \\
\text { capacity of waste } \\
\text { plastic }\end{array}$} \\
\hline & $\begin{array}{l}\text { Bottle } \\
\text { Brick }\end{array}$ & $\begin{array}{l}\text {-easily made } \\
\text {-can utilize waste plastic PET bottles }\end{array}$ & $\begin{array}{l}\text {-the cement layer used in } \\
\text { the construction makes it } \\
\text { susceptible to salinity }\end{array}$ & \\
\hline & $\begin{array}{l}\text { Burnt Clay } \\
\text { Brick }\end{array}$ & $\begin{array}{l}\text {-cheap material } \\
\text { - modular quality } \\
\text {-supported by local masonry practice }\end{array}$ & $\begin{array}{l}\text {-heavier than other masonry } \\
\text { materials } \\
\text {-harms the topsoil (What is } \\
\text { the advantages and } \\
\text { disadvantages of fire clay } \\
\text { brick?, 2018) }\end{array}$ & \\
\hline
\end{tabular}

Table 3. Analysis of Alternate Building Materials

\subsection{CONCEPTUAL FRAMEWORK}

The design concept stems from the combination of floatability and structural rigidity. With the ground floor floatable only and the structural component properly fixed to ground by concrete footing, the semiamphibious structure can effectively withstand both strong cyclonic wind and flood at the same time. With a plinth height of 4 feet, the ground floor can be used up to 9 feet water rise, which covers the normal flood events in the region (shown in figure 8).

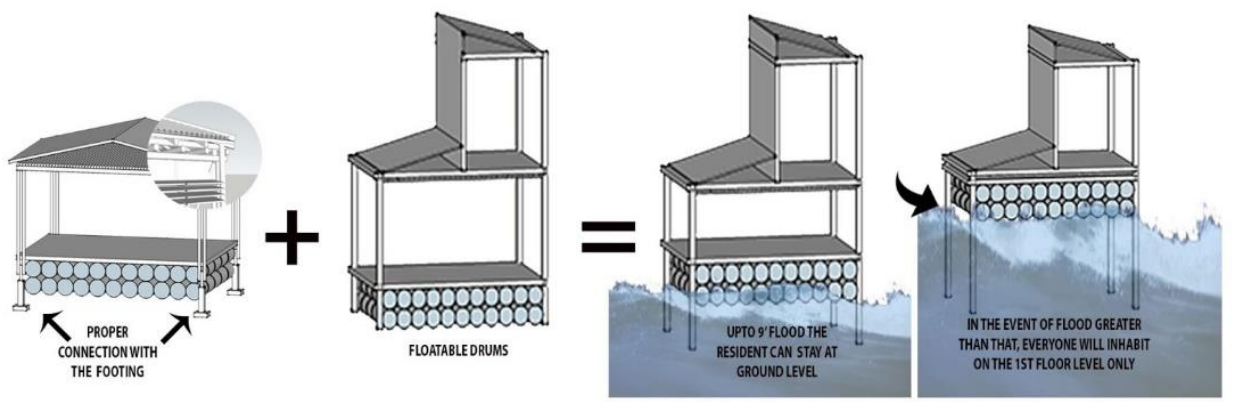

Figure 9, Conceptual Framework (Source: Author)

In the event of extreme cases like the ones seen in the event of a super cyclone like Aila, the family can take shelter in the upper floor, which can remain operational up to14 feet water rise and beyond that level it can be sealed off while the family takes shelter in a cyclone shelter nearby.

\subsection{PROGRAM OUTLINE AND SPACE DISTRIBUTION}

The prototype's space distribution is focused to create a home and workspace for a joint family of 5-6 members (husband \& wife, 2 or 3 children, father and/or mother). Within an area of $1000 \mathrm{sqm}$, the covered 
and semi-covered activity spaces together are $140 \mathrm{sqm}$, and the remaining spaces are divided into courtyard and other open-to sky activity spaces. This combination of covered, semi-covered and open-tosky spatial arrangement is of paramount importance to the local people which is seen from contextual analysis and special attention is taken to preserve it in the prototype (Figure 10). Table 5 below shows spatial distribution in the final phase of the incremental growth.

\begin{tabular}{|c|c|c|c|c|c|c|c|c|c|c|c|}
\hline $\begin{array}{c}\text { Activity } \\
\text { Space }\end{array}$ & $\begin{array}{c}\text { Sleeping } \\
\text { Space }\end{array}$ & $\begin{array}{c}\text { Work } \\
\text { space } \\
\text { /Shop }\end{array}$ & Kitchen & Latrine & Bathroom & $\begin{array}{c}\text { Dawa } \\
\text { khana }\end{array}$ & Granary & $\begin{array}{c}\text { Cattle } \\
\text { Shed }\end{array}$ & Garden & Pond & Courtyard \\
\hline $\begin{array}{c}\text { No. of } \\
\text { Spaces }\end{array}$ & 3 & 2 & 1 & 1 & 1 & 1 & 1 & 1 & 1 & 1 & 1 \\
\hline $\begin{array}{c}\text { Space } \\
\text { Type }\end{array}$ & \multicolumn{3}{|c|}{ Covered } & \multicolumn{3}{|c|}{ Semi-covered } & \multicolumn{3}{c|}{ Open to sky } \\
\hline
\end{tabular}

Table 4. Space Distribution
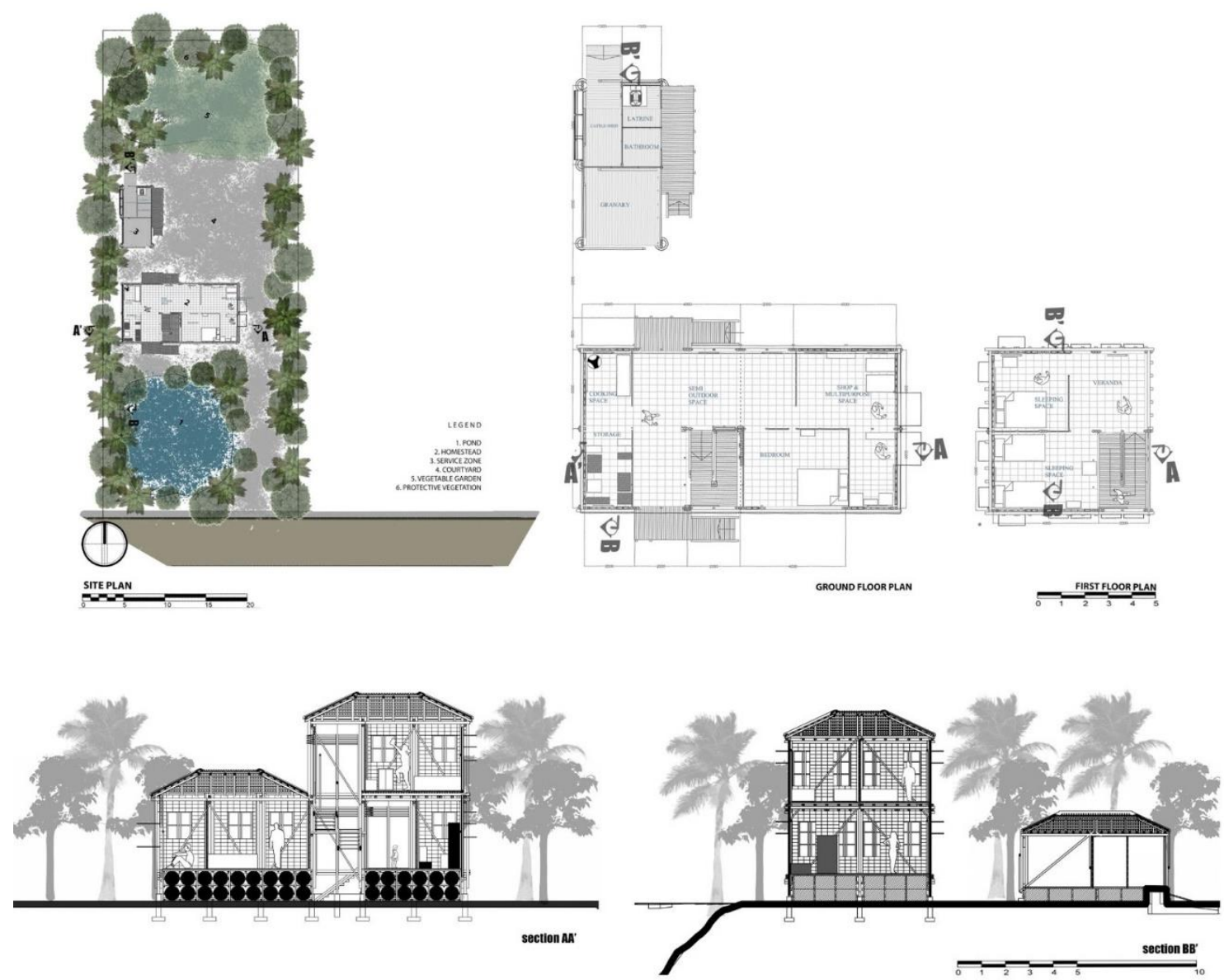

Figure 10, Site plan (upper left), Floor plan (upper right), Section (lower) (Source: Author)

\subsection{INCREMENTAL CAPACITY}

The living area module can be incrementally grown in four phases, from phase 1 (72 sqm) to two-storied phase 2 (108 sqm) (see figure 11) while the secondary module (18 sqm) containing granary, latrine, washroom, cattle shed will be kept the same throughout the incremental growth. It allows the homestead to grow as the family members grow in number and their financial condition improves gradually. The basic phase-1 module is appropriate for a single family with provisions for workspace and all basic amenities, in the latter phase the area of storage, workspace and living area is grown incrementally as the structure goes through the transition of growing then vertically to meet the needs of the inhabitants. 

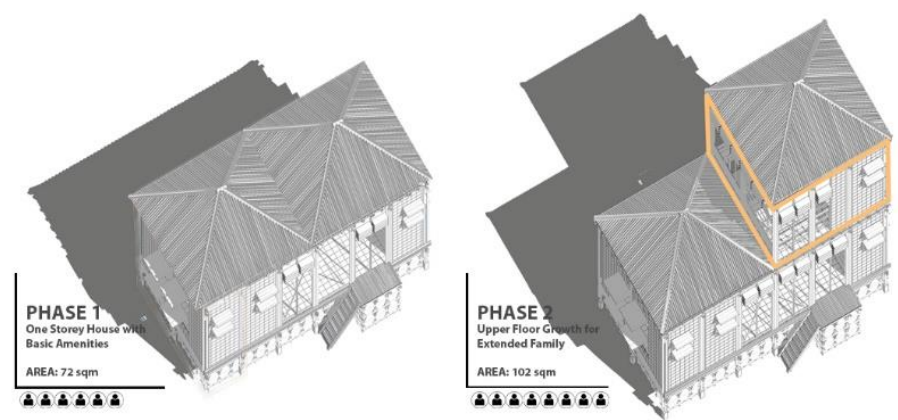

Figure 11, Incremental Growth of the Homestead Prototype (Source: Author)

\subsection{MODULAR STRUCTURE}

The modular components can be easily assembled and attached incrementally as the need of the family arises. This helps to create flexibility in the space distribution rather than only one layout scheme. The $3 \mathrm{~m}$ $\mathrm{x} 2 \mathrm{~m}$ grid is followed in the module layout which creates scope for the integration of semi-open and covered spaces in a harmonious way. The dimension of the rectangular housing module has been obtained from the typological study of the local vernacular housing scenario and the capacity of bamboo as a structural element. The exploded axonometric analysis of the homestead prototype (Figure 12) shows how the structure is merged to create flexible spaces that connect with different outdoor spaces.
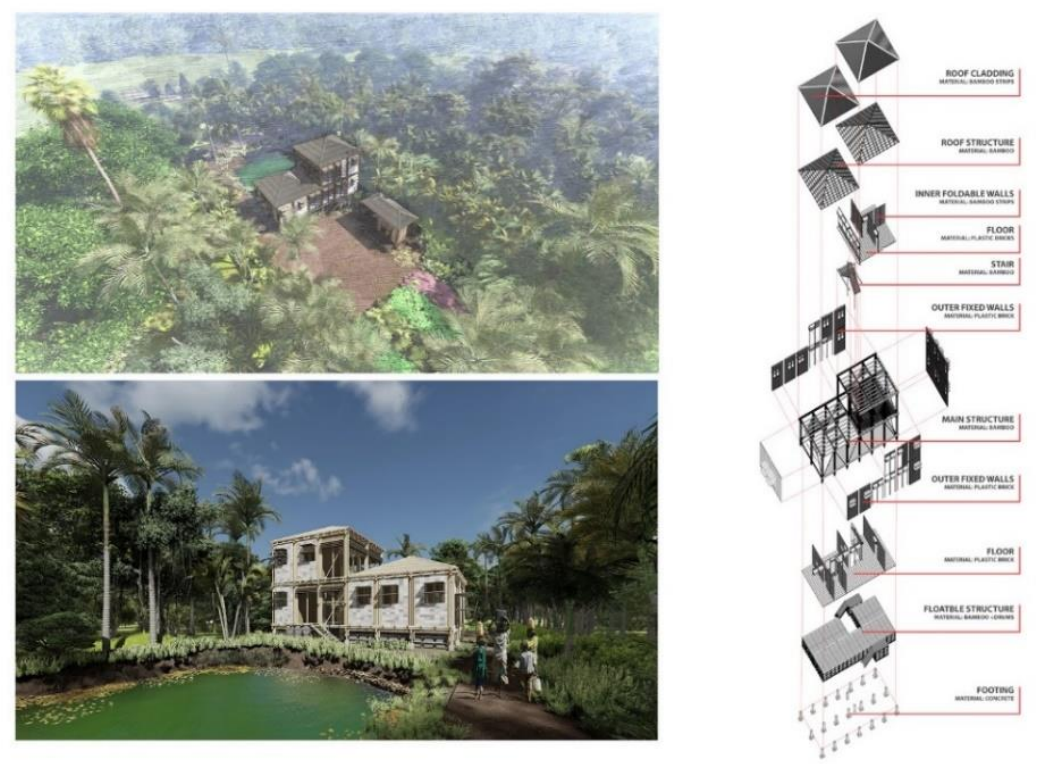

Figure 12, Aerial render (upper left), Perspective render (lower left), Exploded axonometric view (right)

7.6. DISASTER ADAPTABILITY

(Source: Author)
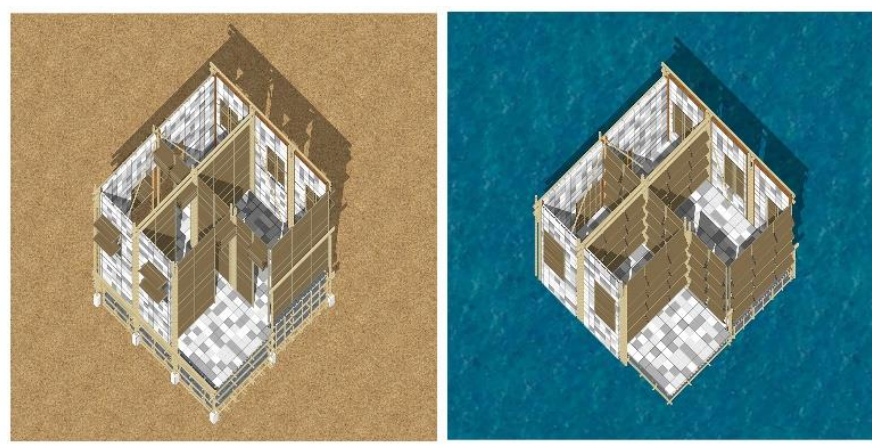

Figure 13, Wall Adaptability with water rise (normal-left, flood-right)

(Source: Author) 
In the existing scenario a mere water level rise of 2-3 feet causes the disruption of local livelihoods. But through the prototype design normal activities can be maintained in the normal flood scenario upto 9 feet water level rise (as shown in the figure 13). The outer plastic brick walls remain fixed with the bamboo structure. The inner walls have vertical folding mechanism, which have attachments with the floor and with the bamboo beams. In normal condition, the walls can remain straight. But in the event of water rise, these walls can fold up to the necessary level (Figure 13). In this way, if the floor height is 6-7 feet (in case 9 feet water rise), the ground floor can be used. When the water rises more than that, the family can move to the second floor for protection. Because of using plastic brick, the submergence of water cannot deteriorate the material quality, making it durable.

This allows the flourishing of the economy in the area as the homestead shape can be kept open. The existing traditional method of using boats as vehicles will be used to maintain the communication the same as before (Figure 14).
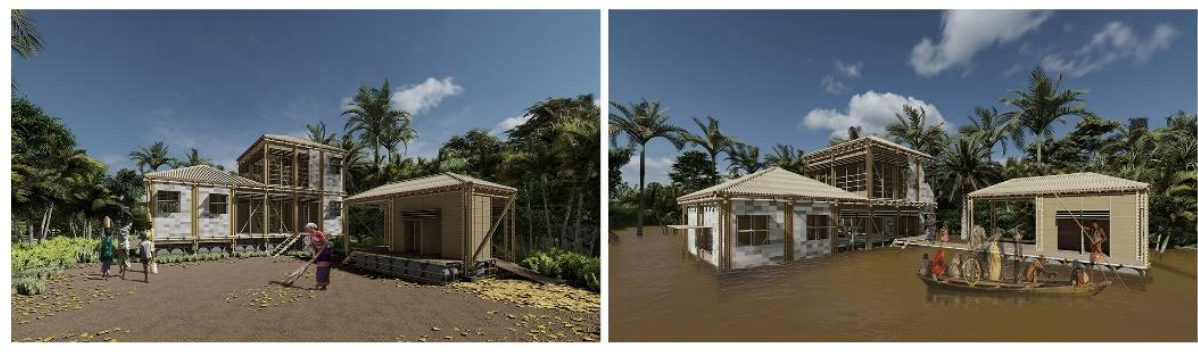

Figure 14, Livelihood adaptability in flood scenario (normal condition- left, flood condition- right) (Source: Author)

\section{Research Outcome and Discussions}

The results can be summarized as achieving a disaster-adaptive, sustainable, and resilient homestead prototype through the non-experimental research. The adverse effect that the traditional building materials pose on the forest can be lessened through the alternative use of materials discussed in the research.

Some of the limitations of the research lies in determining the cost-effective scenario of the plastic bricks in the present market of Bangladesh as the technology discussed is not mass produced yet in the country, although the other building materials such as bamboo, steel drums etc. are found to be far cheaper than timber, bricks etc. Further discussions can be conducted for having an experimental research based on the results found in similar contexts and observe the upgrading of livelihood and empowerment of community.

\section{Conclusion}

Climate change has put forward the question of sustainability, a necessary one that needs to be rethought and implemented to achieve resilience of the community. The vernacular use of space is one of greatest tools that we have in hand which can be utilized to its maximum capacity using sustainable and recycled materials. The research focuses on achieving sustainability through disaster-adaptive measures so that the community can fight together against the changing climate scenario. The homestead prototype not only empowers the people directly but also lessens adverse effects on the surrounding environment passively. So, the more the community focuses on utilizing such sustainable measures while rebuilding, the forest can also heal itself and grow to protect the human settlements against future climate disasters.

\section{References}

Ali Manik, J., Khan S., 2007. Big Blow to the Sundarbans. The Daily Star, [online] Available at: $<$ https://www.thedailystar.net/news-detail-12339> [Accessed 30 June 2021].

Aziz, A. and Paul, A., 2015. Bangladesh Sundarbans: Present Status of the Environment and Biota. Diversity, 7(3), pp.242-269.

Banglapedia. 2014. Shyamnagar Upazila - Banglapedia. [Online] Available at: $<$ https://en.banglapedia.org/index.php/Shyamnagar_Upazila> [Accessed 30 June 2021].

Dhaka Tribune, 2021. Plastic waste recycled into bricks stronger than concrete. [Online] Available at: 
<https://www.dhakatribune.com/world/africa/2021/02/05/kenyan-recycles-plastic-waste-into-bricksstronger-than-concrete?fbclid=IwAR2ZWQg0Gc-jIFqJMgGywYtraKq0Vo9V8seVGstTh4GNUv1xdVQUn31sBc> [Accessed 7 November 2021].

Ghosh, O., 2015. Seaweed cultivation ushers waves of change in the Sundarbans. Deutsche (DW), [online] Available at https://www.dw.com/en/seaweed-cultivation-ushers-waves-of-change-in-the-sundarbans/a-18861596 [Accessed 30 June 2021].

Ghosh, S., 2020. Cracks in the shield: How the Sundarbans is dying and making Bengal prone to cyclones. [Online] Newslaundry. Available at: <https://www.newslaundry.com/2020/12/18/cracks-in-the-shield-how-thesundarbans-is-dying-and-making-bengal-prone-to-cyclones> [Accessed 30 June 2021].

Ghosh, S., 2020. URBAN MINING AND SUSTAINABLE WASTE MANAGEMENT. 1st ed. Singapore: SPRINGER, pp.195201.

Hornaday, F., 2020. Bamboo and carbon sequestration: Saved by net zero - Bambu Batu. [Online] Bambu Batu. Available at: <https://bambubatu.com/bamboo-and-carbonsequestration/?fbclid=IwAR0SxGOyXPWEEGtYpfWhkmZK0YbPx60dIDbK9TNBySmHN4By-TK_-NlJD4w> [Accessed 8 November 2021].

Jalais, A., 2010. Forest of Tigers - People, Politics and Environment in the Sundarbans. 1st ed. London: Taylor and Francis.

Lbre.stanford.edu. n.d. Frequently Asked Questions: Benefits of Recycling / Land, Buildings \& Real Estate. [Online] Available at: <https://lbre.stanford.edu/pssistanford-recycling/frequently-asked-questions/frequentlyasked-questions-benefits-recycling> [Accessed 7 November 2021].

Mukherjee, N., 2019. How our floating homes will help people in flood-prone countries. The Conversation, [online] Available at: <https://theconversation.com/how-our-floating-homes-will-help-people-in-flood-pronecountries-118064?fbclid=IwAR0t_YVZGqm_qKD14jdeWAsnn_HqkjSW4Nl43BChACRnVaAdf9662sCbC7A> [Accessed 7 November 2021].

Munshiganjup.satkhira.gov.bd. 2014. Profile of Munshiganj Union. [Online] Available at: <http://munshiganjup.satkhira.gov.bd/sites/default/files/files/munshiganjup.satkhira.gov.bd/page/5b726 e4d_1c4b_11e7_8f57_286ed488c766/Union\%20profile_Munshigonj-shy_2014.pdf> [Accessed 30 June 2021].

Nishat, B. (2019). Landscape narrative of the Sundarban: Towards collaborative management by Bangladesh and India (No. 133378, pp. 1-207). The World Bank

Pond Boss Forum. 2010. How many 55 gallon drums for this size dock?. [Online] Available at: $<$ https://forums.pondboss.com/ubbthreads.php?ubb=showflat\&Number=235830> [Accessed 7 November 2021].

Purvis, K., 2015. Years of the floods: building homes to withstand the weather - in pictures. The Guardian, [online] Available at: <https://www.theguardian.com/global-development-professionalsnetwork/gallery/2015/apr/21/flood-cyclone-resistant-buildings-asiagallery?fbclid=IwAR33f_Z9erYc8LKr69xDkEPIm2scTJMP0pcKjYiVtrAvy-kMMD-wvPS3z2Y> [Accessed 7 November 2021].

Recycled Rebuild. 2020. Open-Source: Recycled Brick. [Online] Available at: <https://www.recyclerebuild.org/recycledbrick> [Accessed 30 June 2021].

Search, I. and Drums, P., n.d. Plastic 55 Gallon Drum: What Is It? How Is It Used? Types. [online] Iqsdirectory.com. Available at: <https://www.iqsdirectory.com/articles/55-gallon-drum/plastic-55-gallondrum.html?fbclid=IwAR1KPWRTM168aBpNH34pzLmo4WDXctT_Vz8I88jxknlv2c4Mvnl72F-IgRg> [Accessed 7 November 2021].

Slideshare.net. 2018. What is the advantages and disadvantages of fire clay brick?. [Online] Available at: $<$ https://www.slideshare.net/ColumbiaMachineEngineering/what-is-the-advantages-and-disadvantagesof-fire-clay-brick-125512979> [Accessed 8 November 2021].

South Asia Journal. 2020. Bangladesh: Coastal districts hit hard by Amphan. [Online] Available at: <http://southasiajournal.net/bangladesh-coastal-districts-hit-hard-by-amphan/> [Accessed 30 June 2021]

The Constructor. 2021. Bamboo as a Building Material - its Uses and Advantages in Construction. [Online] Available at: $<$ https://theconstructor.org/building/bamboo-as-a-building-material-uses-advantages/14838/> [Accessed 8 November 2021]. 